\title{
Complete Bibliography of Eugenie C. Scott
}

\author{
Adam M. Goldstein • Glenn Branch
}

Published online: 27 May 2010

(C) Springer Science+Business Media, LLC 2010

\begin{abstract}
Bibliographic references for all works authored by Eugenie C. Scott are provided, including her contributions to the publications of the National Center for Science Education and to other sources. The publication history of the various NCSE publications is explained.
\end{abstract}

Keywords Creationism - Intelligent design •

Eugenie C. Scott • National Center for Science

Education (NCSE) • Bibliographic references •

Evolution education

\section{Introduction}

Dr. Eugenie C. Scott's contributions to the body of written work about evolution distinguishes her as sui generis: scientist, scholar, educator, leader, and activist. In addition to the publications of the National Center for Science Education, she has published in scientific journals such as Nature and Science, journals in science education-including Evolution: Education and Outreach-and books and periodicals about science, religion, politics, and culture. As well, she has written on topics in physical anthropology, the discipline

\footnotetext{
A. M. Goldstein $(\varangle)$

Department of Philosophy, Iona College,

715 North Avenue, New Rochelle,

NY 10801, USA

e-mail: z_californianus@shiftingbalance.org

G. Branch

National Center for Science Education,

P.O. Box 9477, Berkeley, CA 94709-0477, USA

e-mail: branch@ncse.com
}

in which she earned her Ph.D. at the University of Missouri-Columbia, writing about dental evolution in pre-Columbian Peru.

The references below were obtained from the NCSE itself, and from Dr. Scott's vita, which she supplied. They have been checked for accuracy and completeness. Some papers appear in more than one of the publications listed below and are cross-referenced.

\section{From the General Literature}

As would be expected, Dr. Scott has authored journal articles, articles in collections of scholarly contributions, and essays in a range of outlets. Books and articles, including contributions to collections, are listed in the Section "Books and Articles," book reviews in the Section "Reviews of Books and Other Media."

Books and Articles

Branch, Glenn and Eugenie C. Scott. 2003. The antievolution law that wasn't. The American Biology Teacher 65: 165-6.

2008. Overcoming obstacles to evolution education: In the beginning. Evolution: Education and Outreach 1: 53-5.

- 2009. The latest face of creationism. Scientific American 300: 90-4.

Branch, Glenn, Eugenie C. Scott, and Joshua Rosenau. 2010. Dispatches from the evolution wars: Shifting tactics and expanding battlefields. Annual Review of Genomics and Human Genetics. Forthcoming. 
Cole, H. P. and Eugenie C. Scott. 1982. Creationscience and scientific research. Phi Delta Kappan April: 555-8. Reprinted in Memorandum to Committees of Correspondence, vol. 3.

Mead, Louise S. and Eugenie C. Scott. 2010. Problem concepts in evolution part I: Purpose and design. Evolution: Education and Outreach 3: 78-81.

Mead, Louise S. and Eugenie C. Scott. 2010. Problem concepts in evolution part II: Cause and chance. Evolution: Education and Outreach 3. In issue 2 (this issue).

Miller, Jon D., Eugenie C. Scott, and Shinji Okamoto. 2006. Science communication: Public acceptance of evolution. Science 313: 765-6.

Scott, Eugenie C. and Glenn Branch, eds. 2006. Not in our classrooms: Why intelligent design is wrong for our schools. Boston: Beacon.

Scott, Eugenie C. 1973. Genetic techniques. In T. C. Hutchinson, ed., Laboratory Methods in Physical Anthropology. Columbia, MO: Museum of Anthropology.

—. 1973. Why teeth? Missouri Archaeological Newsletter no. 270.

- 1976. Game playing in anthropology. UK Teaching News and Notes 2.

- 1979. Dental wear scoring technique. Physical Anthropology 51: 213-17.

- 1979. Increase of tooth size in prehistoric coastal Peru, 10,000 B.P.-1,000 B.P. American Journal of Physical Anthropology 50: 251-8.

1979. Principal axis analysis of dental attrition data. American Journal of Physical Anthropology 51: 203-12.

- 1980. The concept of race in the latter part of the 20th century. Central Issues in Anthropology 2: 69-114.

-1982. Just when you thought it was safe to teach evolution. American Rationalist 27: 55-7.

- 1982. Replication production for scanning electron microscopy: A test of materials suitable for use in field settings. Journal of Microscopy 125: 337-42.

—. 1982. Scientific creationism: School boards may have to decide. Kentucky School Board Journal 1.

- 1984. Anthropology and scientific creationism. A brochure prepared at the request of the AAA designated "American Anthropological Association E3 10/84."
- 1984. Estimation of total water and fatness from weight and height: Inaccurate for lean women. American Journal of Physical Anthropology 64: 83-7.

- 1987. Anti-evolutionism, scientific creationism, and physical anthropology. Yearbook of Physical Anthropology 30: 21-39.

—. 1987. Creationism V: Just when you thought it was safe to teach evolution. Physical Anthropology News 6: 1-5.

1987. Evolution a lost cause? California Science Teachers Journal 17: 14-5.

-1989. Evolution: Strong presence in new science framework. California Classroom Science 1: 1.

- 1992. The evolution of creationism. In A. Must Jr, ed., Why We Still Need Public Schools, pp. 139-55. Buffalo: Prometheus.

1993. The social context of pseudoscience. In J. H. Langdon and M. E. McGann, eds, The Natural History of Paradigms, pp. 338-54. Indianapolis: University of Indianapolis Press.

- 1993. Us and them, nature and humanism. Free Inquiry 13.

- 1994. Creationism: The growing threat. Freedom Writer pp. 1, 8.

_. 1994. Good songs. Science 263: 308.

1994. Keep science free from creationism. Insight on the News 10: 29-31.

-1994. The struggle for the schools. Natural History 103: 10-13.

- 1995. Science and Christianity are compatiblewith some compromises. The Scientist 9: 12.

1996. Creationism. In D. Levinson and M. Ember, eds, Encyclopedia of Cultural Anthropology, pp. 252-4. New York: Henry Holt.

1996. Creationism, ideology, and science. In P. R. Gross, N. Levitt, and M. W. Lewis, eds, The Flight from Science and Reason, pp. 505-22. New York: New York Academy of Sciences.

1996. Dealing with antievolutionism. In Judy Scotchmoor and F. K. McKinney, eds, Learning from the Fossil Record, no. 2 in The Paleontology Society Papers, pp. 15-28. Reprinted in Reports of the NCSE, vol. 17. 
—. 1996. Monkey business: Creationists regroup to expel evolution from the classroom. The Sciences 36: $20-5$.

1996. Scientific creationism. In G. Stein, ed., Encyclopedia of the Paranormal, pp. 670-9. Amherst NY: Prometheus.

- 1997. Antievolution and creationism in the United States. Annual Review of Anthropology 26: 263-89.

—. 1997. Creationism. In F. Spencer, ed., History of Physical Anthropology: An Encyclopedia, pp. 295-8. Garland.

- 1997. Creationists and the Pope's statement. Quarterly Review of Biology 72: 401-6.

- 1997. Evolution and creation: Current controversies. In N. T. Boaz and A. C. Almquist, Biological Anthropology: A Synthetic Approach to Human Evolution, pp. 28-9. Prentice Hall.

- 1998. Two kinds of materialism. Free Inquiry 18: 20.

—. 1999. "But I don't believe in evolution!" The science teacher's dilemma. Journal of Religion and Education 26: 67-75.

- 1999. Evolution devolves in Kansas. Anthropology News 40: 21.

- 1999. Evolution: Not in Kansas anymore. Geotimes 44: 21-2.

- 1999. Problem concepts in evolution: Cause, purpose, design, and chance. In P. H. Kelley, J. Bryan, and T. Hansen, eds, The Evolution-Creation Controversy II: Perspectives on Science, Religion, and Geological Education, pp. 169-81. Paleontological Society Short Course.

1999. The science and religion movement: An opportunity for improved public understanding of science? Skeptical Inquirer 23: 29-31. Reprinted in Reports of the NCSE vol. 23 and in P. Kurtz, ed, Science and Religion: Are they compatible?, pp. 111-16, 2003, Amherst, NY: Prometheus.

- 1999. Science, religion, and evolution. In Judy Scotchmoor and Dale A. Springer, eds, Evolution: Investigating the Evidence, Vol. 9 of The Paleontological Society Special Publications, pp. 361-80.

-2000. Educators have hard choices; nationally, not just in Kansas. Science 289: 869d-71d.
- 2000. Not (just) in Kansas anymore. Science 288: $813-5$.

—. 2000. Fighting talk. New Scientist 166: 46-7.

- 2000. Just when you thought it was safe to teach evolution. Freethought Today 17: 8-9.

- 2001. Creationism, evolution, and antievolutionism. In Neil J. Smelser and Paul B. Baltes, eds, International Encyclopedia of Social and Behavioral Sciences, pp. 2888-92. New York: Pergamon.

- 2001. My favorite pseudoscience. In Paul Kurtz, ed., Skeptical Odysseys, pp. 245-58. Prometheus.

2002. Creation science: A continuing threat to education. In Dean Memering and William Palmer, eds, Discovering Arguments: An Introduction to Critical Thinking and Writing with Readings, pp. 137-40. Saddle River, NJ: Prentice Hall.

- 2002. Creationism bill rejected by Senate: Santorum amendment stirs controversy. Research News and Opportunities in Science and Theology 2: 12.

2002. The nature of change: Evolutionary mechanisms give rise to basic structural differences. Natural History 111: 79. Reprinted in In-Young Chang and Jennifer Curry, Evolution. Bronx, NY: H. W. Wilson, pp. 63-5.

- 2002. Still waiting for ID proponents to say more than "evolution is wrong". Research News and Opportunities in Science and Theology 2.

- 2004. The creation-evolution continuum: How to avoid classroom conflicts. Skeptic 10: 50-4. First appeared in Reports of the NCSE vol. 19.

- 2004. Evolution vs. Creationism: An introduction. Westport, CT: Greenwood.

—. 2005. Creationism. In R. C. Selley, L. R. M. Cocks, and I. Plimer, eds, Encyclopedia of Geology, Vol. 1, pp. 381-6. Boston: Elsevier.

2005. Evolution vs. Creationism: An introduction. Berkeley, CA: University of California Press. Softcover.

- 2005. In my backyard: Creationists and California. California Wild 58: 6-11.

- 2006. Countering creationism with drive-by science. General Anthropology 13: 1-5.

- 2006. Creationism and evolution: It's the American way. Cell 124: 449-51. 
—. 2006. Introduction. In Judy Diamond, ed., Virus and the Whale: Exploring Evolution in Creatures Small and Large, pp. xi-xiv. Arlington VA: National Science Teachers Association Press.

- 2006. The once and future intelligent design. In Eugenie C. Scott and Glenn Branch, eds, Not In Our Classrooms, pp. 1-27. Boston: Beacon Press.

- 2006. Streakers, strollers, and readers. Museums and Social Issues 1: 5-6.

- 2007. Creationism lite: Intelligent design as the new antievolutionism. In Laurie Godfrey and Andrew J. Petto, eds, Scientists Confront Creationism: Intelligent Design and Beyond, pp. 59-109. New York: W. W. Norton.

- 2007. Evolution, creationism, and the myths of nature. In Robert J. Miller, ed., The Future of the Christian Tradition in the Second Axial Age, pp. 17995. Polebridge Press.

- 2007. What's wrong with the "teach the controversy" slogan? McGill Journal of Education 42: 307-15.

- 2008. Interview of Eugenie C. Scott, Executive Director, National Center for Science Education. Evolution: Education and Outreach 1: 74-76. Interview by Mick Wycoff.

2009. American antievolutionism: Retrospect and prospect. In Michael Ruse and Joseph Travis, eds, Evolution: The First Four Billion Years, pp. 370-99. Cambridge, MA: Harvard University Press.

- 2009. Evolution vs. Creationism: An introduction. 2nd ed. Westport, CT: Greenwood.

- 2009. Evolution vs. Creationism: An introduction. 2nd ed. Berkeley University of California Press. Softcover.

- 2009. Newsmaker interview: Eugenie Scott toils in defense of evolution. Science 324: 1250-1. Interview by Yudhijit Bhattacharjee.

- 2009. Overcoming obstacles to evolution education: Science standards evolve. Evolution: Education and Outreach 2: 538.

- 2010. Dobzhansky was right: Let's tell the students. BioEssays 32: 372-4.

- 2010. Listening to teachers. Evolution: Education and Outreach 3. In issue 2 (this issue).
Scott, Eugenie C. and C. J. Bajema. 1982. Height, weight, and fertility among the participants of the Third Harvard Growth Study. Human Biology 54: 501-16.

Scott, Eugenie C. and Glenn Branch. 2002. "Intelligent design" not accepted by most scientists. School Board News 22: 2. 2 July issue.

Scott, Eugenie C. and Glenn Branch. 2003. Antievolutionism: Changes and continuities. BioScience 53: 282-5.

- 2003. Evolution: What's wrong with "teaching the controversy". Trends in Ecology and Evolution 18: 499502.

- 2004. Assaults on evolution have evolved as well. San Jose Mercury News February 15, P1, P6.

- 2004. Response to Langen and to Meyer. Trends in Ecology and Evolution 19: 116-7.

- 2005. Design on trial. The Scientist 23: 14. December 5, December 19 combined issue.

- 2005. Evolution: Just teach it. USA Today August 15: 13A. Reprinted in Robert Atwan, ed., America Now: Short readings from recent periodicals, 2007, Boston: Bedford/St. Martin's, 376-9.

2008. Overcoming obstacles to evolution education: The OOPSIE compromise-a big mistake. Evolution: Education and Outreach 1: 147-9. Reprinted in Reports of the NCSE vol. 28.

2009. Creationism du jour: The "evidence against evolution". Free Inquiry 29: 30-3.

- 2009. Overcoming obstacles to evolution education: Don't call it "Darwinism". Evolution: Education and Outreach 2.

Scott, Eugenie C., Glenn Branch, and Nicholas J. Matzke. 2005. Creationist sticker stock. United Press International 18 January.

Scott, Eugenie C. and H. P. Cole. 1985. The elusive scientific basis of creation "science". Quarterly Review of Biology 60: 21-30.

Scott, Eugenie C. and B. R. DeWalt. 1980. Subsistence and dental pathology etiologies from prehistoric coastal Peru. Medical Anthropology 4: 263-90.

Scott, Eugenie C. and F. E. Johnston. 1982. Critical fat, menarche, and the maintenance of menstrual cycles: A critical review. Journal of Adolescent Health Care 2: 249-60. 
- 1986. Science, nutrition, fat, and policy: Tests of the critical fat hypothesis. Current Anthropology 26: 463-73.

Scott, Eugenie C. and Nicholas J. Matzke. 2007. Biological design in science classrooms. Proceedings of the National Academy of Sciences, USA 104 Supplement 1: 8669-76.

Scott, Eugenie C., Nicholas J. Matzke, and Glenn Branch, et al. 2004. The morphology of Steve. Annals of Improbable Research 10: 24-9.

Scott, Eugenie C. and Kevin Padian. 1997. The new antievolutionism - and what to do about it. Trends in Ecology and Evolution 12: 84.

—. 1997. Reply from K. Padian and E. C. Scott. Trends in Ecology and Evolution 12: 228.

Reviews of Books and Other Media

The first title of each listing below is that of the reviewed work; all other information is about the review itself, except for the names of the reviewed works' authors' names.

Bibliographic information for reviews not listed here appears below in Sections "From Creation/Evolution" and "From Creation/Evolution Newsletter."

Scott, Eugenie C. 1978. [Reviews of] Heredity and Environment; Darwin's Finches; Heredity; Darwin and the Theory of Natural Selection, Mendel's Experiments; Gregor Mendel (films). American Anthropologist 80: $495,502, \& 503$.

- 1980. Variation in Morphology of Teeth, by R. M. S. Taylor. Human Biology 52: 343-6.

- 1984. The Politics of Reproductive Ritual, by K. E. Paige and J. M. Paige. Social Biology 31: 324-7.

- 1985. Fertility, Biology and Behavior, by J. Bongaarts and R. G. Potter. Medical Anthropology Quarterly 16: 81.

- 1985. The Phenomenon of Man Revisited, by Edward Dodson. American Journal of Physical Anthropology 68: 305-7.

- 1986. Infanticide: Comparative and Evolutionary Perspectives, by G. Hausfather and S. B. Hrdy. Quarterly Review of Biology 61: 149-51.

- 1987. The Paluxy River Footprint MysterySolved, by J. Cole and Laurie Godfrey. American Anthropologist 9: 215-6.
1991. The Darwinian Paradigm, by Michael Ruse. American Journal of Physical Anthropology 84: 490-2.

1993. Created from Animals, by James Rachels. Journal of Human Evolution 24: 508-10.

1993. Cult Archaeology and Creationism, edited by F. Harrold and R. Eve. American Antiquity 58: 789-90.

1993. Darwin on Trial, by Phillip Johnson. Creation/Evolution 13: 36-47. Issue 33.

1995. Evolution, by Mark Ridley. Quarterly Review of Biology 70: 509-10.

—. 1997. Connected Knowledge: Science, Philosophy and Education, by Alan Cromer. Nature 389: 248-9.

- 1998. The Trouble with Science, by Robin Dunbar. Isis 89: 585-6. Reprinted in Reports of the NCSE vol. 18.

-2000. The Creation/Evolution Controversy: A Battle for Cultural Power, by Kary D. Smout. Isis 91: 600-1.

- 2001. Icons of Evolution, by Jonathan Wells. Science 292: 2257-8.

2004. Defending Evolution: A Guide to the Creation/Evolution Controversy, by Brian J. Alters and Sandra M. Alters. Trends in Ecology and Evolution 17: 10. Reprinted in Trends in Genetics 18: 163 and Reports of the NCSE vol. 22.

- 2006. Handbook of Evolution, vol. 2, edited by Franz M. Wuketits and Francisco Ayala. Quarterly Review of Biology 81: 396.

- 2008. Life as It Is: Biology for the Public Sphere, by William F. Loomis. Nature 452: 690-1.

- 2008. The Evolution-Creation Struggle, by Michael Ruse. American Journal of Psychology 121: 328-34.

- 2009. Why Evolution is True, by Jerry Coyne. Nature 458: 34.

Scott, Eugenie C. and Alan D. Gishlick. 2004. Evolution, third edition, by Mark Ridley. Quarterly Review of Biology 79: 422-3.

Scott, Eugenie C. and T. C. Sager. 1992. Darwin on Trial, by Phillip Johnson. Creation/Evolution 12: 47-6. Issue 31. 


\section{From Memorandum to Committees of Correspondence}

The Memorandum started publication in 1981; it was published irregularly. Issues in 1981, 1982, 1983 and 1984 were entitled Memorandum to Liaisons for Committees of Correspondence. It was renamed Creation/Evolution Newsletter in 1984.

Creation-Science and Scientific Research. Vol. 3; 11-12. With 1st author Henry P. Cole. Reprint of Cole and Scott 1982.

\section{From Creation/Evolution Newsletter}

One volume per year of six issues each was published, some issues being combined; volumes were numbered 4 through 8. Creation/Evolution Newsletter seems to have been published primarily for the benefit of NCSE's members. None of the content is available online. In 1987, its name was again changed, to NCSE Reports (see Section "From NCSE Reports" below).

The format for references to works published in Creation/Evolution Newsletter is as follows.

\section{Article Title, issue number; page range.}

This is the format used for references to all works in NCSE publications listed below.

Volume 6

A Message From NCSE's Executive Director. 6; 2.

Volume 7

Annual Meeting Symposium Attracts Lively Crowd. 1; 3-4.

Louisiana Decision Announced. 4; 1, 5-8.

[Untitled letter.] 5; 6. First appeared in Time, July 20, 1987.

Audio-Visual Task Force Needs Help. 6; 2.

Will the Real Committees of Correspondence Please Stand Up? 6; 3-4.

What's Going on at Your School Board. 6; 4.

Pressures Increase on Baptist Colleges. 6; 9-10.

\section{Volume 8}

ICR Protests California Science Revision. 6; 5-6.

Review of Gould's Time's Arrow, Time's Cycle. 6; 19.

\section{From NCSE Reports}

NCSE Reports started as Memorandum to Liaisons for Committees of Correspondence in 1981, which was renamed Creation/Evolution Newsletter in 1984. It took its new name in 1987 and then was merged with Creation/Evolution in 1997, producing Reports of the NCSE. Some of the articles from NCSE Reports (not all) can be found at http://ncse.com/media/ncser.

Volume 9

Without Darwin. 2; 3.

Good News, Bad News from Texas. 2; 4-6.

The Garden of Eden in Omaha, You Say? 2; 18-19.

Disturbing Trends at the National Science Foundation. 2; 20 .

New Creationist Book on the Way. 2; 21.

Will ICR be Approved to Grant Graduate Degrees? $4 ; 21$.

Examples of Creationist Methodology. 5; 10.

Dannemeyer Attempting to Get Amendment Out of Committee. 6; 20.

Volume 12

Creationists No Longer Invited to Peoria Public Schools. 1; 6.

Clinton Not Governor When Arkansas Law Passed. $1 ; 7$.

Mormon Church Stance on Evolution. 1; 20-1.

Creationist Cases Blooming. 2; 1, 3, 5.

Supreme Court Rules in Prayer Case. 2; 4.

Sea World Chickens of the Sea. 2; 6.

Televangelist Promotes Of Pandas and People. 2; 19.

Bible-Science Association View of Ecology. 2; 20.

Committees of Correspondence Revival, Birth. 2; 23.

Textbook Runs Afoul of Cal School Board. 3; 4.

Update on Lake County, Florida. 3; 4.

Televangelist Dobson Slams California FrameworkBut Promotes NCSE! 3; 6.

NCSE at AAAS in February. 3; 8.

Welcome New Members. 3; 8 .

Robert S. Dietz Honored. 3; 9.

NCSE and PFAW Cooperate on Textbook Reviews. $3 ; 11$.

NCSE and PFAW Cooperate on New Textbook Reviews. 4; 9.

Colin Patterson, Cladistics, and Creationists. 4; 14-15. Other People's Ark. 4; 22. 
Volume 13

Vista, CA District in Turmoil over Creationism. 1; 1, 5, 18.

Update on Honig, Successor. 1; 3.

ICR Graduates Masters Degree Holders. 1; 9.

Cal District Continues Creationist Activity. 2; 1, 22-3.

In the Trenches .... 2; 6 .

What's Behind the Vista and Louisville Strategies. 2; 8 .

Another Creationism Trial Brewing? 2; 9.

Cold Comfort for Creationists in Ruse Talk. 2; 10-11.

Floods Provide Once-in-a-Lifetime Opportunity. 2; 19.

Creation Research Society Gets Arizona Headquar-

ters. $2 ; 21$.

Creationism Trial Headed Off. 3; 1, 5.

California Poll Shows Creationism Support, Strong

Religious Right. 3; 9.

Gallup Reports High Level of Belief in Creationism. $3 ; 9$.

Christian Educators Seek Route to Teaching Creationism. $3 ; 18$.

NCSE Symposium Scheduled at AAAS 1994. 3; 19.

Dean Kenyon and "Intelligent Design Theory" at San

Francisco State U. 4; 1, 5, 13.

Florida Resolution Promoting Creationism Introduced.

$4 ; 3$.

Louisiana District Narrowly Rejects "Alternate Theories of Origin." 4; 4, 5.

Creationism Provides "Balance" for Public Television. $4 ; 8$.

[Untitled letter]. 4; 21. Originally appeared in the Wall Street Journal, sec. A, p. 17, col. 1.

Alaska SBE Contemplates "Equal Time." 4; 29.

Usborne Wimps Out? 4; 31.

Florida Creationist to ICR? 4; 41.

Vista, CA, Update. 4; 43.

Volume 14

[Note: Volume 13, issue 4 and volume 14, issue 1 were combined.]

Peloza Case Remanded to District Court. 2; 1, 7, 9.

School District Requires "Evolution Only a Theory"

Disclaimer. 2; 8.

Wisconsin Zoo Promotes Adam and Eve. 3; 5. With second author Molleen Matsumura.

St. Paul, MN Institutes 4-6 Evolution Curriculum. 3; 5.

Peloza Appeal Reversed! 4; 4, 5.

Gould Promotes Creationist Book?? (No). 4; 6.

Elections Bring Good News to FL, CA Districts, Not

Such Good News to LA. 4; 8 .
Volume 15

Waldorf Schools Teach Odd Science, Odd Evolution. 4; 20, 21.

Did the AHA Beget the NCSE? 2; 9.

One-Third of Fairfax, VA School Board Candidates in Support of Creationism. 3; 7.

State of Alabama Distorts Science, Evolution. 4; 10, 11.

Volume 16

NCSE Board Announces New Publication Format. 1; $10,11$.

Washington School District Wrestles with Creationism, "Intelligent Design Theory." 1; 17.

Close Ohio House Vote Scuttles "Evidence Against Evolution" Bill. 1; 18.

Big Bang Glue-on in Kentucky. 2; 1, 9.

Evolving Euphemisms-Balanced Treatment Mutates to "Evidence Against Evolution." 2; 5, 18.

Sound Familiar? 3; 17.

Texas Textbook Adoptions: Whither (Wither) Evolution? $4 ; 6$.

Evolution Protested at Tennessee Textbook Adoptions. $4 ; 7$.

\section{From Creation/Evolution}

Creation/Evolution originally began publication under the auspices of the American Humanist Association in 1980 , but was acquired by the NCSE in 1990. It was merged with NCSE Reports in 1997, producing Reports of the NCSE (see Section "From Reports of the NCSE" below). Creation/Evolution was published in numbered issues, ending with 39; on the NCSE's web site for Creation/Evolution (below), volume numbers have been added in retrospect. All back issues are available at $\mathrm{http}: / / \mathrm{ncse} . \mathrm{com} / \mathrm{media} /$ cej in PDF format.

Darwin on Trial by Phillip Johnson. 31; 47-56. With 2nd author Thomas C. Sager.

Darwin Prosecuted: Review of Johnson's Darwin on Trial. 33; 36-47.

Debates and the Globetrotters. 35; 22-6.

Again, Johnson Gets it Wrong. 37; 26-9.

\section{From Reports of the NCSE}

As described above, in 1997, NCSE Reports merged with Creation/Evolution to form Reports of the NCSE, 
which starts at volume 17. Selected content from Reports of the NCSE is available at http://ncse.com/ media/rncse.

\section{Volume 17}

Anti-Evolutionists Form, Fund Think Tank-OldEarth Moderates Poised to Spread Design Theory. 1; 25, 26.

Tippecanoe and Creationism Too. 2; 4.

Australian Geologist Plimer Loses Lawsuit. 2; 4, 5.

Arizona Regent Protests Evolution Institute Move. 2; 7,8 .

AAAS Sponsors "Epic of Evolution" Conference. 3; $7,8$.

NABT Statement on Evolution Evolves. 4; 4, 5.

Dealing with Anti-Evolutionism. 4; 24-30. First appeared in Scotchmoor and McKinney 1996.

\section{Volume 18}

Answers in Genesis Tries Again for Museum. 1; 4, 5.

NCSE Members Excel at Teaching. 1; 10.

NCSE Members Enjoy Galapagos Islands. 2; 6.

Come with NCSE to the Grand Canyon! 2; 6, 7.

Science and Religion, Methodology, and Humanism. 2; $15-17$.

What's in a Name? Or: Just When You Thought It Was Safe to Name Fossils! 2; 17.

Science and Religion, Christian Scholarship, and Theistic Science: Some Comparisons. 2; 30-2.

Don't Miss the NCSE "Creation/Evolution" Grand Canyon Trip. 3; 7.

NCSE Receives First Stock Donation. 3; 7.

NCSE Creation/Evolution Grand Canyon Trip Challenge. $4 ; 25$.

[Review of] The Trouble with Science. 6; 25. First appeared in Isis 1998.

Volume 19

Textbook Authors Join NCSE in Defending Evolution Education. 1; 9-11.

The Outrageous Idea of Christian Scholarship. 1; 2931.

Bleeding Kansas: What Happened? What's Next? 4; 7-9.

The Creation-Evolution Continuum. 4; 16-17, 21-3. Revised; published in Skeptic 2004.
Volume 20

In Memory of Bob Schadewald. 12; 24.

Twelve Tips for Testifying at School Board Meetings. 12,35 .

Baylor's Polanyi Center in Turmoil. 4; 9.

Lerner Report Announced at AAAS/Fordham Symposium. $4 ; 45$.

[Review of] The Creation-Evolution Controversy: A Battle for Cultural Power. 6; 34-5. First appeared in Isis 2000.

Volume 21

The Big Tent and the Camel's Nose. 12; 39-41. First appeared in The Global Spiral.

Stanley Weinberg, NCSE Founder, Dies. 3/4; 11-13.

PBS Broadcasts Evolution Series. 5/6; 4.

Volume 22

Comments on Richter's "What Science Can and Cannot Say". 12; 23.

[Review of] Defending Evolution: A Guide to the Creation-Evolution Controversy. 12; 51-2. First appeared in Trends in Ecology and Evolution 2004.

Volume 23

NCSE Honors "Friends of Darwin". 1; 7-8.

My Favorite Pseudoscience. 1; 11-16. First appeared in Skeptical Inquirer 2001.

Arthur Strahler Dies. 5/6; 21.

Volume 24

Confronting Creationism: When and How. 6; 23.

Volume 26

Problems with the Intersession Course. 4; 6-9.

Volume 27

NCSE: A Decade in Retrospect. 1/2; 19-20.

NCSE 2007 Grand Canyon Raft Trip: "The Best Ever". $3 / 4 ; 15$.

Volume 28

Anti-Evolution Legislation in the Bayou State. 2; 8-11. With 2nd author Glenn Branch. 
The OOPSIE Compromise-A Big Mistake. 2; 26-8. First appeared in Evolution: Education and Outreach 2008. With 2nd author Glenn Branch.

A Rude Introduction to Expelled. 5/6;11-12.

Bait and Switch: Expelled's Questionable Interview Tactics. 5/6; 12-14. With 1st author Anne D. Holden.

Marketing Expelled. 5/6; 15-17. With 1st author Anne D. Holden.

Expelled Tanks at the Box Office After Big Start. 5/6; 17-18.

Meet the Martyrs: Richard Sternberg. 5/6; 36-8. With 1st author Carrie Sager.
Expelled Errors: Evolution. 5/6; 43-6. With 1st author Joshua Rosenau.

Expelled Errors: "Intelligent Design." 5/6; 46-8. With 2nd author Joshua Rosenau.

Expelled Errors: Science and Religion. 5/6; 49-50. With 2nd author Peter M. J. Hess.

Volume 29

The Latest on Expelled. 2; 9.

The January Amendments. 3; 11-14. With 1st author Steven Newton and 2nd author Joshua Rosenau. 